\title{
Role of nurses in the assessment
}

\section{and management of chemotherapy-related side effects in cancer patients}

REVIEW

This article was published in the following Dove Press journal:

Nursing: Research and Reviews

28 August 2014

Number of times this article has been viewed

\author{
Helen Roe' \\ Elaine Lennan ${ }^{2}$ \\ 'Department of Clinical \\ Oncology, North Cumbria \\ University Hospitals NHS \\ Trust, Carlisle, ${ }^{2}$ Chemotherapy \\ Unit, University Hospital \\ Southampton NHS Foundation \\ Trust, Southampton, UK
}

Correspondence: Elaine Lennan University Hospital Southampton NHS Foundation Trust, Tremona Rd, Southampton, SOI64YD, UK

Tel +44 7733265222

Email elaine.lennan@uhs.nhs.uk

Helen Roe

North Cumbria University Hospitals

NHS Trust, Cumberland Infirmary,

Carlisle, CA27HY, UK

Tel +44 7825733296

Email helen.roe@ncuh.nhs.uk

\begin{abstract}
Chemotherapy services in the UK have been the subject of national policy directives for the past decade. These directives, amongst other things, include the development of nurseled services; however, progress has been slow. This paper looks at the evidence for nurse-led services and discusses the competencies and skills required. Chemotherapy nurses have been much respected for their drug knowledge, information-giving, and communication skills, but in the past have lacked assessment skills. This paper offers a guide to assessment of chemotherapy patients, including the process of chemotherapy, key information needs, and consent, taking account of the recent 2013 National Cancer Patient Experience Survey. It discusses in detail the common side effects of treatment and their management, outlining international common toxicity criteria to guide assessment. Finally, it briefly outlines a new initiative of acute oncology services that have enhanced not only the quality of services but the safety of patients receiving chemotherapy.
\end{abstract}

Keywords: chemotherapy, nurse-led care, acute oncology service, toxicity management

\section{Background}

Modern delivery of cancer services in the UK is guided by clear Department of Health (DOH) policy. ${ }^{1-4}$ The past 15 years have seen a stepped change in cancer services with the aim of improving outcomes to match those seen in Europe and the USA. Much of this policy direction called for specialization and a drive to develop services across professional boundaries rather than remaining in professional silos. ${ }^{1}$ Amongst other possibilities, this shift has created opportunities for nurses to be fully involved in the assessment and management of patients undergoing chemotherapy. However, implementation has been slow. The commitment to nurse-led clinics and services was further reinforced in the National Chemotherapy Advisory Group report. ${ }^{4}$ Included in this report was reference to concerns about the safety of chemotherapy and to promote future nurse-led care within this culture was a clear endorsement of the value of nurse led care. ${ }^{4}$ Whilst the policy endorsement was clear, there remains very few published studies offering evidence of safe care in the chemotherapy setting. 5

The role of the chemotherapy nurse is much respected, and there is a wealth of knowledge within this group about side effects and their management. ${ }^{5}$ However, the development of additional skills within this group to meet the demands of policy and service needs has been ad hoc. The United Kingdom Oncology Nursing Society (UKONS) has since offered guidance to help practitioners and employers ensure individuals are fit for practice in regard to nurse-led chemotherapy services and to ensure patient care is not compromised. ${ }^{6}$ 
This paper offers a guide to assessment of chemotherapy patients, including the process of chemotherapy, key information needs, and consent, taking account of the recent 2013 National Cancer Patient Experience Survey. ${ }^{7}$ Finally, it briefly outlines a new initiative of acute oncology services that has enhanced not only the quality of services but the safety of patients receiving chemotherapy.

\section{Nurse-led chemotherapy clinics}

Whilst one of the recommendations of the National Chemotherapy Advisory Group report is the further development of nurse-led chemotherapy services, the decision to treat and with which regimen remains the realm of the oncologist. The nurse, as an important member of the multidisciplinary team, can implement the agreed plan, assessing and adjusting treatment as it progresses. ${ }^{4}$ However, it is vital that patients remain in contact with their oncologist at differing points in their treatment journey, and this is usually determined by local policy.

The purpose of the clinical review before each cycle of chemotherapy is to identify any toxicities experienced previously, assess the individual's fitness to continue, and implement any planned changes in the treatment pathway. A nurse undertaking this review needs to be a competent practitioner who possesses the necessary knowledge about the specific chemotherapy the patient is receiving and its intent. A national comprehensive competency package is yet to evolve, but specific competencies in relation to this review have been developed by Skills for Health. ${ }^{8}$ Additionally, the National Prescribing Centre has produced a single competency framework for prescribers which aids practice. ${ }^{9}$ These have yet to become mainstream in practice and UKONS is currently working on a competency package to suit all models of chemotherapy review practice. ${ }^{10}$

Chemotherapy has significant and predictable toxicities, the most serious of which are likely to develop while the patient is at home between treatment cycles. Usually these resolve with time. In the clinic, the nursing assessment establishes the presence of any toxicities and determines the need for intervention. If the patient is fit, chemotherapy can continue. Importantly, the practitioner needs to be a skilled communicator to enable them to obtain key information from the patient regarding how they are feeling and not base their assessment only on what their eyes tell them. ${ }^{6}$ Advanced history-taking skills are required because patients are often reluctant to describe how bad the side effects actually have been, for fear of their chemotherapy being stopped. This was a very clear finding in the National Confidential Enquiry into Perioperative Deaths audit regarding deaths occurring within 30 days of chemotherapy. ${ }^{11}$ Similarly, the National Patient Safety Agency has issued alerts with regard to oral medicines and the need to pay particular attention to patient compliance. ${ }^{12}$ Indeed, ongoing support throughout a treatment course, not just at clinic appointments, was found to increase compliance with and the safety of oral chemotherapy drugs. ${ }^{13}$

As well as the physical assessment, it is essential that the nurse assesses the psychological impact of having a diagnosis of cancer and receiving treatment for it. This includes how well the patient is coping with the impact of receiving chemotherapy on day-to-day life. Uncertainty regarding the outcomes of treatment can also add to distress felt by patients and their families. ${ }^{14,15}$

The presence of physical symptoms can often have a detrimental effect on an individual's psychological well-being. Body image changes due to weight loss/gain, hair loss, skin texture, nail changes, potential for fatigue, stoma management, and limb loss can confound the problems of psychological distress. The individual's perception of self is challenged, and a transition to a new self is needed. ${ }^{16}$ An assessment framework known as the holistic needs assessment can be used to identify and address these issues. This framework has been translated into a concerns framework, including a distress thermometer, which asks a patient to rate their psychological well-being. Given the longevity of treatment pathways and the many aspects of a disease trajectory, this self-assessment is likely to change. Therefore, it is extremely important that assessments of well-being are undertaken at regular intervals because this is an important aspect of quality care. ${ }^{17}$ Referrals to appropriate support should be made if required.

To assist the nurse in assessment, it is essential that systems are in place to record any symptoms the patient might develop. General well-being is recorded using performance status and holistic needs assessment tools, and toxicities are recorded using common toxicity criteria, examples of which are cited below. This toxicity tool is also embedded within clinical trials protocols, and so ensures consistency of practice across clinical areas, whether administering trial or standard chemotherapy regimens.

The ongoing assessment of a patient receiving chemotherapy is often undertaken in a variety of setting and ways, varying from the more formal clinic setting in a hospital to the community or by telephone. ${ }^{6}$ Studies have also been carried out using mobile telephone software to allow patients to input their toxicities, which are then relayed to the professionals 
caring for them. These systems generate alerts to the health professional who then contacts the patient to discuss the side effects experienced and develop a plan for the patient. ${ }^{18}$

\section{Patient information needs}

To enable a patient to make decisions regarding possible treatment options, appropriate, up-to-date information regarding the aim of the treatment being recommended, possible side effects and how to manage them, the expected outcomes of the treatment, and also the outcome of not proceeding with treatment need to be given. ${ }^{19}$ Other considerations include any clinical trials that might be appropriate. Within the UK, Macmillan Cancer Care and Cancer Research UK provide high-quality, regimen-based information that meet the required standard of DOH policy. ${ }^{19-21}$ However, there remains much work to do in this regard. The 2013 Cancer Patient Experience Survey reported significant variations in the proportion of patients reporting that side effects were explained in an understandable way, with the range being $61 \%-89 \%$. $^{7}$ There is also a need for local information to be developed, ie, facilities such as car parking, information centers, pharmacy services, and support groups. Information such as this can help navigate a patient through the complicated journey of chemotherapy and reduce anxiety. ${ }^{22}$ Indeed, the 2013 Cancer Patient Experience Survey reported that only $54 \%$ of patients were offered such advice. ${ }^{7}$ This local information is an ideal opportunity for professionals to work with their patient and carer groups to ensure that the information they provide is in the form required by patients.

The process of information-giving is ongoing and one in which all members of the multidisciplinary team have a role to play. However, it is a key component of the role of the chemotherapy nurse to ensure that both patient and carer have the required information to make an informed decision about treatment options. ${ }^{23}$ This need is heightened with orally administered chemotherapy, and to support nurses, the Multinational Association of Supportive Care in Cancer has developed a comprehensive tool for providing such information. ${ }^{24}$

The process of information-giving often starts at the initial consultation when specific information regarding chemotherapy is discussed and supported by written information. Many organizations provide patients and their families with a prechemotherapy consultation between the initial clinic visit and commencing chemotherapy, because this gives patients an opportunity to digest the information and ask questions prior to commencing treatment. ${ }^{4}$ It is imperative that the nurse providing this consultation is knowledgeable about chemotherapy and is able to articulate what will happen whilst receiving chemotherapy, including possible side effects and their management.

The consultation should be structured and supported by local documentation, yet tailored to meet the individual patient's needs. It should not be rushed. A patient diary to record any symptoms the patient may experience is often provided, and importantly, contact details for a 24-hour helpline are highlighted. ${ }^{23}$ There must also be time to rehearse what the patient should do in the event of specific side effects, eg, neutropenic sepsis. Ensuring that the patient has understood the information provided, particularly in relation to oncological emergencies, is vitally important. Specifically, a teach-back technique can be used whereby patients are asked to relay back in their own words what their understanding has been. ${ }^{25}$

In providing information, it has become increasingly important to consider the information needs of carers during the chemotherapy journey. ${ }^{14,26}$ Carers have expressed a need for different information and sometimes need a "difficult" conversation without the patient being present. Given the reliance of chemotherapy services on carers' understanding and reinforcing key messages, supporting the carer is an area that needs further focus. One could argue that nurses are best placed for this and now have a real opportunity to engage with carers through the nurse-led clinics, given that holistic care and holistic needs assessment is at the core of professional practice. $^{17}$

The DOH has produced a manual of chemotherapy standards to guide services, and these require all organizations to demonstrate that provision of this information is in place. ${ }^{19}$ The results of the Quality Health (2014) Chemotherapy patient experience survey 2013 National report, were published in January $2014^{27}$ and this will allow services to understand the quality of their local service, from the patient information perspective as well as other aspects of the patient's experience.

\section{Nurse-led chemotherapy clinics in practice}

As already discussed, nurses are supported by the DOH to develop nurse-led chemotherapy clinics. The primary purpose of the clinic is to assess the patient's ongoing suitability to receive chemotherapy. The focus of the consultation is to determine the presence of any toxicities of treatment. Side effects, if any, have often resolved by the time the patient returns to clinic, so it is important to determine how badly the patient was affected in the interval since the last treatment. 
This is determined by history-taking, physical assessment, and evaluation of the patient's physiological well-being and performance status or ability to manage day-to-day tasks. Based on this assessment, adjustments can be made to their chemotherapy and supportive medicines as necessary, including potentially delaying treatment for a few days to allow full recovery from a particular symptom. UKONs considers nurse prescribing skills as the gold standard for chemotherapy clinics though it is possible to practice without prescriptive authority. ${ }^{6}$ However, this model relies on medical staff to prescribe on behalf of the nurse, which creates limitations in terms of professional practice.

\section{Common side effects and their management}

All side effects of chemotherapy are assessed according to common toxicity criteria. ${ }^{28}$ In addition, UKONS has developed a triage tool to help in the recognition of the urgency of a particular problem (Figure 1).

\section{Neutropenic sepsis}

Neutropenic sepsis, or febrile neutropenia, is a lifethreatening complication of treatment and as such is rightly placed at the top of any discussion on the side effects of chemotherapy. The incidence varies, and depends on the myelosuppressive nature of the chemotherapy drug/s being given, the performance status of the patient, and the extent of comorbid conditions. ${ }^{29}$ It is caused by the toxic effect of the chemotherapy on neutrophils, leaving the patient struggling to mount an immune response should an infection occur (Table 1). Many patients on chemotherapy will be neutropenic, but it is the single presence of a fever that makes this situation an oncological emergency requiring immediate attention. As noted in the triage tool, a single episode of fever prompts a red response, meaning contact the hospital immediately. Others symptoms, such as breathlessness or diarrhea, are been graded less urgent, but in recognition of the potential for a cluster of symptoms, nurses using the tool are educated that any two amber status symptoms must be escalated to a red situation which again means contacting the hospital immediately.

Treatment includes immediate administration of a broad spectrum antibiotic (within an hour) and a full "septic workup" to determine the causative pathogen. ${ }^{30}$ Often a short course of antibiotics is enough to stabilize the patient until the neutropenia resolves, but unfortunately, for others, the infection progresses to septic shock requiring full resuscitative measures. Neutropenic deaths still occur in practice and are particularly devastating, given that they are a treatmentrelated complication rather than a cancer-related concern.

Specific guidelines for nurses regarding the prevention and management of febrile neutropenia have been recommended. ${ }^{31}$ These include:

- developing and reinforcing the implementation of patient care pathways designed to prevent and manage febrile neutropenia

- providing appropriate education on febrile neutropenia for health professionals and patients/families

- providing patients with verbal and written information on the early signs of febrile neutropenia.

Optimal management of febrile neutropenia has been clearly demonstrated in an award-winning care bundle introduced by Foulkes, that documented an improvement in compliance with the neutropenic care pathway from $19 \%$ to $94 \%$, along with benefits in terms of reduced length of stay (from 13.4 days to 6 days) and a reduction in mortality (from $7 \%$ to $4 \%$ ) (personal communication Foulkes, September 2013). This is an excellent example of adherence to care pathways improving outcomes.

\section{Chemotherapy-induced nausea and vomiting}

Chemotherapy-induced nausea and vomiting is one of the most unpleasant side effects of treatment, and is consistently cited by patients as one of their greatest fears when embarking on a treatment course (Table 2). ${ }^{32-35}$ Whilst great strides have been made in the pharmacological management of chemotherapy-induced nausea and vomiting, it is by no means eradicated. A recent survey involving ten cancer centers reported the incidence of moderate to severe nausea as 3\%-40\% and moderate to severe vomiting as $23 \%-66 \%$. Given that this survey addressed patient-reported outcomes, the issue of chemotherapy-induced nausea and vomiting remains current. ${ }^{36}$

The most important risk factor for the development of chemotherapy-induced nausea and vomiting is the emetic potential of the chemotherapy regimen. However, other factors, including age, gender, comorbid conditions, concurrent medications, and alcohol intake also play a part. ${ }^{37}$ Prevention of chemotherapy-induced nausea and vomiting is the ultimate goal, and using appropriate antiemetics depending on the emetogenicity of the chemotherapeutic regimen is key. ${ }^{38}$ Modern antiemetics are very effective in the majority of cases, but this is by no means $100 \%$. Antagonists to 5HT-3 (eg, ondansetron) have no doubt changed the impact of chemotherapy-induced nausea and vomiting, and most recently, 


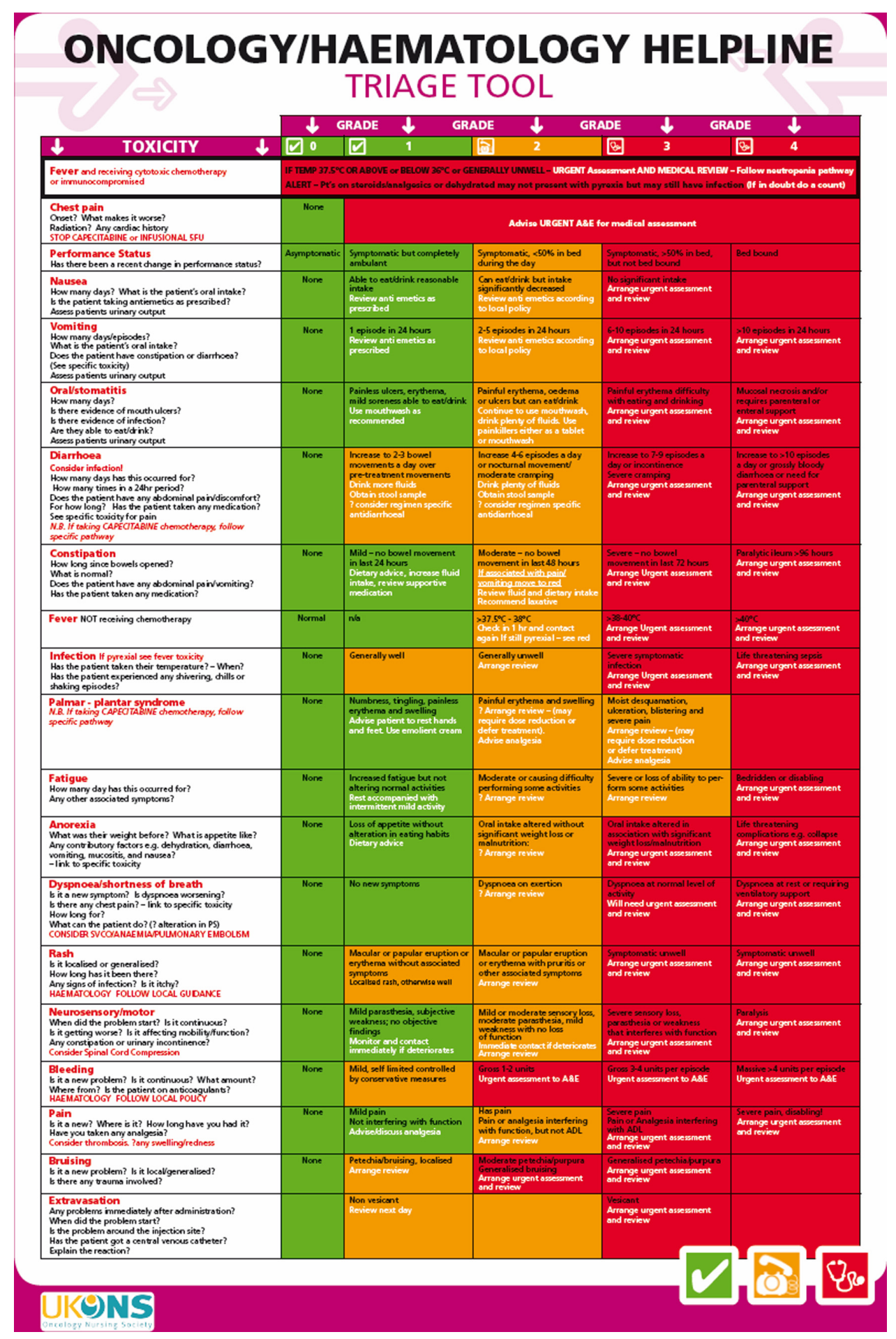

Figure I United Kingdom Oncology Nursing Society triage tool published in 2013.

Note: Reproduced with permission from the United Kingdom Oncology Nursing Society (UKONS). http://www.ukons.org. 9

introduction of NK1 antagonists, eg, aprepitant, is making a similar impact, although these are often restricted due to cost. Nausea remains substantial for some patients, and is one side effect that greatly affects their quality of life. Practice guidance concerning the management of chemotherapyinduced nausea and vomiting is available from the Multi- national Association of Supportive Care in Cancer and the American Society of Clinical Oncology, as well as summary documents from UKONS. ${ }^{10,24,39}$ Nurses have an important role in implementing appropriate strategies to minimize the occurrence of chemotherapy-induced nausea and vomiting. As well as pharmacological agents, advice regarding eating 
Table I Common toxicity criteria $(\mathrm{NCl} 2012)$

\begin{tabular}{|c|c|c|c|c|}
\hline \multirow[t]{2}{*}{ Grade } & I & 2 & 3 & 4 \\
\hline & Mild & Moderate & Severe & Life-threatening \\
\hline Neutrophils & $<1.5 \times 10^{9} / \mathrm{L}$ & $<1.5-1.0 \times 10^{9} / \mathrm{L}$ & $<1.0-0.5 \times 10^{9} / \mathrm{L}$ & $<0.5 \times 10^{9} / \mathrm{L}$ \\
\hline $\begin{array}{l}\text { Febrile } \\
\text { neutropenia }\end{array}$ & - & & $\begin{array}{l}\text { ANC }<1,000 / \mathrm{mm}^{3} \text { with a single } \\
\text { temperature of }>38.3^{\circ} \mathrm{C}\left(101^{\circ} \mathrm{F}\right) \\
\text { or a sustained temperature of } \geq 38^{\circ} \mathrm{C} \\
\left(100.4^{\circ} \mathrm{F}\right) \text { for more than one hour }\end{array}$ & $\begin{array}{l}\text { Life-threatening } \\
\text { consequences, urgent } \\
\text { intervention indicated }\end{array}$ \\
\hline
\end{tabular}

Note: Data from National Cancer Institute. Common Terminology Criteria for Adverse Events (CTCAE) Version 4.0. Available from: http:/levs.nci.nih.gov/ftpl/CTCAE/ CTCAE_4.03_2010-06-14_QuickReference_8.5xII.pdf. Accessed February 2012. ${ }^{79}$ Abbreviations: ANC, absolute neutrophil count; $\mathrm{NCl}$, National Cancer Institute.

little and often, avoiding strong smells, and an understanding that it is okay to abstain from food intake for 24 hours as long as fluid intake is good can be reinforced at treatment sessions. Nonpharmacological interventions, including acupressure and acupuncture, have also been used with some effect. Ginger is also a common, and popular remedy. ${ }^{40-42}$

Prevention of chemotherapy-induced nausea and vomiting remains the goal of antiemetic therapy, as a syndrome of anticipatory nausea is well documented if prevention is not successful. This syndrome involves learned anticipatory symptoms of nausea and/or vomiting when a patient is nearing chemotherapy, meeting personnel, or encountering reminders of treatment. This powerful response is unpleasant and difficult to treat, although lorazepam has be used to good effect. ${ }^{43,44}$

\section{Chemotherapy-induced diarrhea}

Diarrhea is common in patients receiving chemotherapy, but its causes are multifactorial (Table 3). Understanding the probable cause is a key component of taking the history. Direct damage to the mucosa lining the gastrointestinal tract is often thought to be the cause, but overuse of antibiotics, underuse of antidiarrheal agents, malabsorption syndromes, concurrent radiotherapy, and infection are also implicated. ${ }^{45,46}$

Untreated diarrhea can be fatal, and the mainstay of management is early control using agents such as loperamide and ensuring hydration. Octreotide can be tried for persistent diarrhea. ${ }^{47}$ It is important for the patient to understand their own baseline bowel habits before treatment and feel comfortable in discussing and describing their motions. Ongoing diarrhea can have a profound effect on performance status and may interrupt treatment schedules. Patients are reluctant to attend hospital when suffering from diarrhea because it is difficult to travel and embarrassing. In addition, patients are often reluctant to contact help lines a second time if their symptoms resolved during a previous cycle. This is a dangerous situation, and the nurse has an important role in reinforcing messages about when to contact the help line and ensuring medicines are stored and administered safely. Some individuals start to doubt their ability to complete treatment. Certainly left untreated, the sequelae of diarrhea include renal failure, perforation, infection, and death. ${ }^{48,49}$ Anyone presenting with grade 3 and 4 diarrhea needs admission to hospital for hydration and investigation of cause. Updated management guidelines are currently in development and should be available in spring 2014.

\section{Alopecia}

Chemotherapy affects the growth of both cancerous and noncancerous cells. ${ }^{50}$ The root of a hair has a high blood flow, allowing for uptake of chemotherapy. Hair can be lost from all over the body and not just the head, a fact that is often overlooked. ${ }^{51}$ The loss of facial hair for a man can leave them

Table 2 Common toxicity criteria ( $\mathrm{NCl} 20 \mathrm{I} 2)$

\begin{tabular}{|c|c|c|c|c|}
\hline Grade & I & 2 & 3 & 4 \\
\hline Nausea & $\begin{array}{l}\text { Loss of appetite without } \\
\text { alteration in eating habits }\end{array}$ & $\begin{array}{l}\text { Oral intake decreased } \\
\text { without significant weight } \\
\text { loss dehydration or } \\
\text { malnutrition }\end{array}$ & $\begin{array}{l}\text { Inadequate oral calorific or } \\
\text { fluid intake, IV fluids, tube } \\
\text { feedings, or TPN indicated }\end{array}$ & $\begin{array}{l}\text { Life-threatening } \\
\text { consequences }\end{array}$ \\
\hline Vomiting & One episode in 24 hours & $\begin{array}{l}2-5 \text { episodes in } 24 \text { hours, } \\
\text { IV fluids indicated }\end{array}$ & $\begin{array}{l}>6 \text { episodes in } 24 \text { hours, } \\
\text { IV fluids indicated or TPN }\end{array}$ & $\begin{array}{l}\text { Life-threatening } \\
\text { consequences }\end{array}$ \\
\hline
\end{tabular}

Note: Data from National Cancer Institute. Common Terminology Criteria for Adverse Events (CTCAE) Version 4.0. Available from: http://evs.nci.nih.gov/ftpl/CTCAE/ CTCAE_4.03_2010-06-14_QuickReference_8.5xII.pdf. Accessed February 2012. ${ }^{79}$

Abbreviations: IV, intravenous; $\mathrm{NCl}$, National Cancer Institute; TPN, total parenteral nutrition. 
Table 3 Common toxicity criteria $(\mathrm{NCl} 2012)$

\begin{tabular}{|c|c|c|c|c|}
\hline Grade & I & 2 & 3 & 4 \\
\hline Diarrhea & $\begin{array}{l}\text { Increase of }<4 \text { stools per } \\
\text { day over baseline, mild } \\
\text { increase in ostomy output } \\
\text { compared with baseline }\end{array}$ & $\begin{array}{l}\text { Increase of } 4-6 \text { stools per day } \\
\text { over baseline IV fluids indicated, } \\
\text { moderate increase in ostomy } \\
\text { output compared with baseline } \\
\text { not interfering with ADL }\end{array}$ & $\begin{array}{l}\text { Increase of }>7 \text { stools per day over } \\
\text { baseline, incontinence, IV fluids, } \\
\text { hospitalization, severe increase in } \\
\text { ostomy output compared with } \\
\text { baseline, interfering with ADL }\end{array}$ & $\begin{array}{l}\text { Life-threatening } \\
\text { consequences, ie, } \\
\text { hemodynamic collapse }\end{array}$ \\
\hline
\end{tabular}

Note: Data from National Cancer Institute. Common Terminology Criteria for Adverse Events (CTCAE) Version 4.0. Available from: http://evs.nci.nih.gov/ftpl/CTCAE/ CTCAE 4.03 2010-06-14 OuickReference 8.5xII.pdf. Accessed February 2012. ${ }^{79}$

Abbreviations: ADL, activities of daily living; IV, intravenous; $\mathrm{NCl}$, National Cancer Institute.

feeling much younger and possibly less virile. ${ }^{52}$ Alopecia, although not life-threatening, is the most visible side effect of chemotherapy, having the ability to threaten body image and self-confidence (Table 4). ${ }^{53,54}$ In 2008, Hilton et al concluded that, contrary to common belief, men also have negative feelings about hair loss. It can also leave the patient feeling they have lost control of any choice about telling others about their condition and treatment. ${ }^{52}$

Many patients opt for a wig to address their changing body image. Wigs can be obtained through the National Health Service, although provision of wigs varies greatly and patients often need to "top up" the cost. A patient information booklet provides practical advice for patients regarding hair loss, choice of wig, and caring for their hair when it regrows following chemotherapy. ${ }^{55}$

The nurse-led clinic offers an opportunity for the nurse to discuss the psychological impact of alopecia. This includes tips and strategies for managing hair loss as well as sensitively reinforcing messages about regrowth. One aspect that is often avoided is discussion relating to the possibility that the hair might not regrow. Yeager and Olsen outline some of the possible strategies that may assist this process and suggest working more closely with dermatology teams. ${ }^{53}$

\section{Stomatitis}

Stomatitis is a common side effect of chemotherapy, and is characterized by pain and inflammation of the surface of the mucous membrane in the oral cavity. It develops as a direct result of chemotherapy destroying healthy cells in the mouth. Overall, $40 \%$ of people who have chemotherapy as part of their cancer treatment will develop some degree of

Table 4 Common toxicity criteria ( $\mathrm{NCl} 2012)$

\begin{tabular}{lllll}
\hline Grade & I & $\mathbf{2}$ & $\mathbf{3}$ & $\mathbf{4}$ \\
\hline Hair loss & Thinning or patchy & Complete & - & - \\
\hline
\end{tabular}

Note: Data from National Cancer Institute. Common Terminology Criteria for Adverse Events (CTCAE) Version 4.0. Available from: http://evs.nci.nih.gov/ftpl/ CTCAE/CTCAE_4.03_2010-06-14_QuickReference_8.5xll.pdf. Accessed February $2012 .{ }^{79}$

Abbreviation: $\mathrm{NCl}$, National Cancer Institute. stomatitis. ${ }^{56}$ Its severity depends on the type of chemotherapeutic agent and the dose used (Table 5)..$^{57}$

Stomatitis can vary from gum sensitivity to widespread painful ulcers. The duration is short, but can be debilitating and painful for the patient. A patient with stomatitis can suffer from isolation, nutrition problems, and infection. ${ }^{57,58}$ Severely compromised oral mucosa will result in reduction in the chemotherapy dose, with possible consequences in terms of optimal treatment outcome, although the mouth repairs quickly in most patients, with a return to normal health within a few days.

Attention to any dental problems is recommended prior to commencing any chemotherapy treatment and good attention to oral hygiene is recommended thereafter. Oral assessments should be done by the nurse at each visit. Comprehensive advice regarding management of a compromised oral cavity is available from the UK Oral Mucositis in Cancer Group. ${ }^{59}$ Smell and taste changes during chemotherapy can have a significant impact on a patient's ability to eat, which may ultimately lead to weight loss and malnutrition. ${ }^{60,61}$ This side effect could also result in prolongation of other possible side effects, a decrease in the patient's quality of life, poor compliance with treatment, and a possible decrease in response to treatment. ${ }^{62}$ However, because this side effect is not life-threatening, it is often overlooked by professionals. Taste changes affect approximately half of all patients receiving chemotherapy, indicating a need for discussion with the patient before starting treatment..$^{63,60}$

The nurse has a role in suggesting possible strategies to minimize the detrimental impact of chemotherapy ${ }^{63}$ The carer is often an essential part of these discussions, given that they are usually responsible for the cooking. Part of this process should include undertaking both clinical and nutritional assessments and monitoring changes during the course of treatment. ${ }^{61}$

\section{Fatigue}

One of the most frequent and distressing side effects of cancer and chemotherapy is fatigue. ${ }^{64}$ The actual prevalence of fatigue in patients undergoing chemotherapy is unknown, but it is very likely all patients have some degree of fatigue, 
Table 5 Common toxicity criteria $(\mathrm{NCl} 2012)$

\begin{tabular}{llll}
\hline Grade & $\mathbf{2}$ & $\mathbf{2}$ & $\mathbf{3}$ \\
\hline Stomatitis & $\begin{array}{l}\text { Erythema of } \\
\text { the mucosa }\end{array}$ & $\begin{array}{l}\text { Patchy ulcerations or } \\
\text { pseudomembranes }\end{array}$ & $\begin{array}{l}\text { Confluent ulcerations or } \\
\text { pseudomembranes, bleeding } \\
\text { with minor trauma }\end{array}$ \\
\hline
\end{tabular}

Note: Data from National Cancer Institute. Common Terminology Criteria for Adverse Events (CTCAE) Version 4.0. Available from: http:/levs.nci.nih.gov/ftpl/CTCAE/ CTCAE_4.03_2010-06-I4_QuickReference_8.5xII.pdf. Accessed February 2012.79 Abbreviation: $\mathrm{NCl}$, National Cancer Institute.

that persists beyond treatment in some cases (Table 6). ${ }^{65,66}$ Fatigue is a common subjective complaint associated with chemotherapy, and symptoms such as total body tiredness, forgetfulness (often patients describe a "chemo head"), and wanting to rest increases over time during therapy. ${ }^{66,67}$

Management strategies include planning activities and ensuring plenty of rest, although not total rest. There is increasing evidence of the benefit of exercise during treatment to maintain muscle bulk. Ensuring adequate calorie intake and correcting anemia are other measures to consider, along with determining if depression is present.

\section{Hypersensitivity}

Hypersensitivity is a general term used to describe all grades of allergic drug reactions, including anaphylaxis. Whilst the potential for hypersensitivity reactions is present in all patients receiving chemotherapy, it is more common with certain drugs. In particular, there is an increased risk with taxanes (docetaxel and paclitaxel) and many of the targeted monoclonal antibody therapies, eg, trastuzumab, rituximab, and cetuximab. ${ }^{68}$ Patients receiving these drugs are required to have a longer observation period and/or be administered premedication to suppress the immune system. Hypersensitivity reactions are rarely fatal, but are extremely frightening for patients, nurses, carers, and other patients who may be watching. Minor reactions, eg, flushing, mild rash, and itching, can be managed by stopping the infusion and administering additional antihistamines. Once resolved, cautiously restarting the infusion may result in completion of chemotherapy without further problems. However, severe reactions can result in stridor, bronchospasm, and angioedema. In this situation, full resuscitative support is

Table 6 Common toxicity criteria $(\mathrm{NCl} 2012)$

\begin{tabular}{lllll}
\hline Grade & $\mathbf{I}$ & $\mathbf{2}$ & $\mathbf{3}$ & $\mathbf{4}$ \\
\hline Fatigue & Fatigue & Fatigue not relieved & Fatigue not relieved & - \\
& relieved & by rest and limiting & by rest, limiting \\
by rest & instrumental ADL & self-care ADL & \\
\hline
\end{tabular}

Note: Data from National Cancer Institute. Common Terminology Criteria for Adverse Events (CTCAE) Version 4.0. Available from: http://evs.nci.nih.gov/ftpl/ CTCAE/CTCAE_4.03_2010-06-14_OuickReference_8.5xII.pdf. Accessed February 2012. ${ }^{79}$

Abbreviations: ADL, activities of daily living; $\mathrm{NCl}$, National Cancer Institute. required to protect the airway until resolved. In this instance, restarting the infusion even cautiously is not appropriate. Guidelines for the management of hypersensitivity reactions are available from the Resuscitation Council (Table 7). ${ }^{69}$

Should administration of the chemotherapy agent be the optimal treatment in terms of treating the underlying cancer, a desensitization procedure can be attempted. This involves administering sequential doses of the drug and building up tolerance very slowly. This is not without clinical risk, and is both time-consuming and resource-intensive, so should only be used where alternative chemotherapy regimens are not available..$^{70}$

In the nurse-led clinic, the nurse should counsel patients about the possibility of hypersensitivity reactions and ensure support medications are readily available. Patients with previous severe reactions should be referred back to the oncologist.

\section{Peripheral neuropathy}

Peripheral neuropathy is becoming a challenging clinical problem for cancer patients receiving chemotherapy. Several of the commonly used drugs cause peripheral nerve damage (ie, the taxanes and oxaliplatin) and the success of treatment often means patients have several lines of treatment, such that repeated drug administration results in further damage to the nerve endings. ${ }^{68}$ Added to this picture is the complexity of other morbidities, such as diabetes and arthritis, causing considerable distress and difficulty to the patient in terms of activities of daily living.

Symptoms of peripheral neuropathy are variable (Table 8). Drug-induced neuropathy is likely to cause sensory nerve damage, resulting in changes in sensation, along with numbness and burning. Both hands and feet can be affected, and the degree of damage is worsened with increasing duration of treatment. It is for this reason that nursing assessment of fine motor function is crucial at every cycle of treatment. A simple history can pinpoint a problem. Asking searching questions, eg, regarding ability to fasten buttons or send text messages can offer clues. Stumbling when walking can also build a picture of nerve damage. Interrupting treatment or dose reduction may be the appropriate management plan to prevent further debilitating damage. 
Table 7 Common toxicity criteria ( $\mathrm{NCl} 2012)$

\begin{tabular}{|c|c|c|c|c|}
\hline Grade & I & 2 & 3 & 4 \\
\hline Allergic reaction & $\begin{array}{l}\text { Transient flushing or } \\
\text { rash, drug fever }<38^{\circ} \mathrm{C} \text {, } \\
\text { intervention not indicated }\end{array}$ & $\begin{array}{l}\text { Intervention or infusion } \\
\text { interruption indicated responds } \\
\text { promptly to symptomatic } \\
\text { treatment, eg, antihistamines }\end{array}$ & $\begin{array}{l}\text { Prolonged recurrence of symptoms } \\
\text { following initial improvement, } \\
\text { hospitalization required for clinical } \\
\text { sequelae, ie, renal impairment }\end{array}$ & $\begin{array}{l}\text { Life-threatening } \\
\text { consequences, urgent } \\
\text { intervention required }\end{array}$ \\
\hline Anaphylaxis & - & - & $\begin{array}{l}\text { Symptomatic bronchospasm with } \\
\text { or without urticaria, parenteral } \\
\text { intervention indicated, allergy-related } \\
\text { edema, angioedema, hypotension }\end{array}$ & $\begin{array}{l}\text { Life-threatening } \\
\text { consequences, urgent } \\
\text { intervention required }\end{array}$ \\
\hline
\end{tabular}

Note: Data from National Cancer Institute. Common Terminology Criteria for Adverse Events (CTCAE) Version 4.0. Available from: http:/levs.nci.nih.gov/ftp I/CTCAE/ CTCAE_4.03_2010-06-14_QuickReference_8.5xII.pdf. Accessed February 2012.79

Abbreviation: $\mathrm{NCl}$, National Cancer Institute.

Unfortunately there is no treatment available for peripheral neuropathy. Management strategies include preventing further damage, symptomatic relief, and psychological support. ${ }^{71}$ Correcting dietary deficiencies is also thought to be beneficial.

\section{Extravasation}

Extravasation is a potential consequence of receiving intravenous chemotherapy, and is defined as occurring when the chemotherapy agent accidently leaks into the surrounding tissue instead of the intended intravenous or intra-arterial administration site. ${ }^{72}$ Although extravasations are more likely to occur when a peripheral cannula is being used, they can also occur when using central venous access devices, and have the potential to cause further damage. ${ }^{73}$ It is therefore vital that nurses involved in administering intravenous chemotherapy have the knowledge and skills to minimize the risk of an extravasation, detect signs early should they occur, and manage the incident effectively. ${ }^{74}$ Distinguishing cutaneous reactions which are not extravasations, ie, flare reactions, is also important. ${ }^{75}$

Chemotherapy agents are classified according to their potential to cause local damage should they extravasate (Table 9). There are three main classification groups, ie, nonvesicant, irritant, and vesicant ${ }^{72}$ with the latter potentially causing the most harm. Management of extravasation remains controversial, and depends on the chemotherapy agent or agents that have extravasated and the possible antidotes available. ${ }^{73,74}$ Not all extravasations require intervention, but all require monitoring. ${ }^{73,74}$ Management options will vary from "watch and wait", use of an antidote, flush out, or even surgical intervention. ${ }^{72}$ Practical guidelines have been produced jointly by the European Society for Medical Oncology and the European Oncology Nursing Society, and also by UKONS. ${ }^{76}$ However, nurses should consult their local guidelines.

It is difficult to quantify the actual number of extravasations that occur because there is no mandatory reporting system in the UK. Extravasations have the potential to interrupt the patient's planned treatment. ${ }^{73,74}$ Historically, within health care, there has been a reluctance to report extravasations due to the blame culture surrounding them. ${ }^{74}$ Accurate documentation, ideally including photographs and reporting of events prior to, during, and after the event, is a must, especially in view of the potential legal implications. ${ }^{73}$ The nurse plays a number of key roles, including educating the patient concerning possible symptoms of an extravasation and being instrumental in the development of local guidelines, given that they are ideally placed to describe what actually happens in clinical practice as well as being the patient's advocate. ${ }^{75}$

The nurse in the clinic has an ongoing responsibility to carry out vein assessments to ensure no signs of extravasation and to determine if administration of chemotherapy is causing veins to become fragile. The nurse must assess the need for

Table 8 Common toxicity criteria (NCl 20I2)

\begin{tabular}{|c|c|c|c|c|}
\hline Grade & I & 2 & 3 & 4 \\
\hline $\begin{array}{l}\text { Peripheral motor } \\
\text { neuropathy }\end{array}$ & $\begin{array}{l}\text { Asymptomatic, clinical or } \\
\text { diagnostic observations only, } \\
\text { intervention not indicated }\end{array}$ & $\begin{array}{l}\text { Moderate symptoms limiting } \\
\text { instrumental ADL }\end{array}$ & $\begin{array}{l}\text { Severe symptoms limiting } \\
\text { self-care } A D L \text {, assistive } \\
\text { device indicated }\end{array}$ & $\begin{array}{l}\text { Life-threatening } \\
\text { consequences, urgent } \\
\text { intervention indicated }\end{array}$ \\
\hline $\begin{array}{l}\text { Peripheral sensory } \\
\text { neuropathy }\end{array}$ & $\begin{array}{l}\text { Asymptomatic, loss of deep } \\
\text { tendon reflexes, or paresthesia }\end{array}$ & $\begin{array}{l}\text { Moderate symptoms limiting } \\
\text { instrumental ADL }\end{array}$ & $\begin{array}{l}\text { Severe symptoms limiting } \\
\text { self-care ADL }\end{array}$ & $\begin{array}{l}\text { Life-threatening } \\
\text { consequences, urgent } \\
\text { intervention indicated }\end{array}$ \\
\hline
\end{tabular}

Note: Data from National Cancer Institute. Common Terminology Criteria for Adverse Events (CTCAE) Version 4.0. Available from: http:/levs.nci.nih.gov/ftpl/CTCAE/ CTCAE 4.03 2010-06-14 QuickReference 8.5xII.pdf. Accessed February 2012.79

Abbreviations: $\mathrm{ADL}$, activities of daily living; $\mathrm{NCl}$, National Cancer Institute. 
Table 9 Common toxicity criteria $(\mathrm{NCl} 2012)$

\begin{tabular}{|c|c|c|c|c|}
\hline Grade & I & 2 & 3 & 4 \\
\hline Extravasation & & $\begin{array}{l}\text { Erythema with associated } \\
\text { symptoms (eg, edema, pain, } \\
\text { induration, phlebitis) }\end{array}$ & $\begin{array}{l}\text { Ulceration or necrosis, severe } \\
\text { tissue damage, operative } \\
\text { intervention indicated }\end{array}$ & $\begin{array}{l}\text { Life-threatening } \\
\text { consequences, urgent } \\
\text { intervention indicated }\end{array}$ \\
\hline $\begin{array}{l}\text { Injection site } \\
\text { reaction }\end{array}$ & $\begin{array}{l}\text { Tenderness with or without } \\
\text { associated symptoms (eg, } \\
\text { warmth, erythema, itching) }\end{array}$ & $\begin{array}{l}\text { Pain, lipodystrophy, edema, } \\
\text { phlebitis }\end{array}$ & $\begin{array}{l}\text { Ulceration or necrosis, severe } \\
\text { tissue damage, operative } \\
\text { intervention indicated }\end{array}$ & $\begin{array}{l}\text { Life-threatening } \\
\text { consequences, urgent } \\
\text { intervention indicated }\end{array}$ \\
\hline
\end{tabular}

Note: Data from National Cancer Institute. Common Terminology Criteria for Adverse Events (CTCAE) Version 4.0. Available from: http:/levs.nci.nih.gov/ftpl/CTCAE/ CTCAE 4.03 2010-06-14_OuickReference_8.5x।I.pdf. Accessed February 2012.79

Abbreviation: $\mathrm{NCl}$, National Cancer Institute.

a central access device, counsel the patient accordingly, and refer to the appropriate service for placement.

\section{Other side effects}

Nurses need a full awareness of the toxicities associated with chemotherapy regimens including for any new drugs. Just a small sample has been given above, and readers are directed to the full common toxicity criteria for a complete guide. ${ }^{77}$

\section{Acute oncology services}

Despite thorough assessments to determine fitness to receive chemotherapy, urgent situations do occur because of the toxic nature of such treatment. Most chemotherapy is given in the ambulatory care setting, so these urgent complications tend to start in the patient's home. Therefore, it is important to ensure that patients are aware of whom to contact, and that when contact is made, services are equipped and prepared to advise in a timely manner.

Much of the management of the side effects of chemotherapy is preventative, but patients frequently need assessment, advice, and treatment for complications. Patients who develop toxicities from chemotherapy are now benefiting from a new concept known as the acute oncology service. ${ }^{19}$ These service directives are in response to the 2008 National Confidential Enquiry into Perioperative Deaths report that examined deaths within 30 days of receiving chemotherapy. ${ }^{11}$ This report noted that many patients were unsure regarding whom and when to ring for help, and also highlighted an organizational lack of response should patients make contact. Acute oncology services now offer timely and appropriate advice to patients and are beginning to have a noticeable impact on patient outcomes. Integrating the 24-hour chemotherapy help lines into acute oncology services means patients can be reassured and kept at home or fast tracked into the hospital. Many of these services are nurse-led (although not in isolation from the multidisciplinary team) and work in tandem with the chemotherapy nurses. To assist nurses in triage and management of these patients, UKONS has developed assessment guidelines and management pathways, as shown in Figure 1.

An excellent example of this initiative in action is the implementation of a nurse-led, integrated acute oncology service in Pan Birmingham Cancer Network and Sandwell and West Birmingham Hospitals NHS Trust. Evaluation has been three-fold, with a focus on reducing bed days, using the door-to-needle time for neutropenic sepsis as an efficiency and delivery indicator, and gauging the value of the service to patients.

A reduction in the mean length of stay from 10 days to 6.5 days and in median length of stay from 5 days to 2 days suggest that, from September 2011 to September 2012, a 35\% (1,116 bed days) reduction in the benchmarked 3,189 chemotherapy-related emergency admissions were achieved. In addition, this service reduced the need for admission to intensive care from $17 \%$ to $3 \%$. This means that acute oncology services is on track to save $£ 247,000$ in its first year based on bed savings of $£ 221$ per day, but more importantly, the service has demonstrated an ability to provide timely and appropriate advice to patients. ${ }^{78}$

The particular focus of these services includes early recognition and treatment of neutropenic sepsis, metastatic spinal cord compression, and cancer of unknown primary. In addition, early interventions for grade 1 and 2 toxicities arising from treatment can sometimes prevent escalation of symptoms and consequent morbidity. ${ }^{11}$

\section{Conclusion}

Chemotherapy nurses have been much respected for their technical, information-giving, and communication skills. Most recently, chemotherapy nurses have been developing assessment and management skills for supporting patients through their chemotherapeutic pathway. This trend will continue as we future-proof chemotherapy services, and using assessment tools and common toxicity criteria is important for consistency. Nurses have a real opportunity to add value to the patient pathway by undertaking this exciting new role, 
but not before they are deemed competent to do so and never in isolation from the multidisciplinary team.

\section{Disclosure}

The authors report no conflicts of interest in this work.

\section{References}

1. Department of Health. The Nursing Contribution to Cancer Care. London, UK: Her Majesty's Stationery Office; 2000a.

2. Department of Health. The NHS Cancer Plan. London, UK: Her Majesty's Stationery Office; $2000 \mathrm{~b}$.

3. Department of Health. The Cancer Reform Strategy. London, UK: Her Majesty's Stationery Office; 2007.

4. Department of Health. Manual of Cancer Services; Chemotherapy measures version 2.0. London, UK: National Cancer Peer Review, National Cancer Action Team; 2013. Available from: http:/www.cquins. nhs.uk. Accessed September 20, 2013.

5. Farrell C, Lennan E. Nurse-led chemotherapy clinics: issues for the prescriber. Nurse Prescribing. 2013;11:352-361.

6. Lennan E, Vidall C, Roe H, Smith J, Farrell C. Best practice in nurse-led chemotherapy review: a position statement from the United Kingdom Oncology Nursing Society. London, UK: United Kingdom Oncology Nursing Society; 2012. Available from: http://www.ncbi.nlm.nih.gov/ pmc/articles/PMC3413734/. Accessed February 15, 2014.

7. Quality Health. National Cancer Patient Experience Survey (2012-2013). Available from: http://www.quality-health.co.uk/surveys/ national-cancer-patient-experience-survey. Accessed February 16, 2014.

8. Skills for Health. http://www.skillsforhealth.org. [homepage on the Internet]. Accessed January 14, 2014.

9. National Prescribing Centre. A single competency framework for all prescribers. London, UK: National Prescribing Centre; 2012. Available from: http://www.npc.co.uk/improving_safety/ improving_quality/resources/single_comp_framework.pdf. Accessed February 16, 2014

10. United Kingdom Oncology Nursing Society (UKONS). http://www. UKONS.org. [homepage on the Internet]. Accessed Sep 2013.

11. National Confidential Enquiry into Patient Outcome and Death. For Better, for Worse? London, UK: National Confidential Enquiry into Patient Outcome and Death; 2008. Available from: http://www.ncepod. org.uk/2008sact.htm. Accessed February 14, 2014.

12. National Patient Safety Agency. Risks of incorrect dosing of oral anticancer medicines. London, UK: National Patient Safety Agency; 2008. Available from: http://www.npsa.nhs.uk/corporate/news/patient-safetyrisks-of-incorrect-dosing-of-oral-anti-cancer-medicines/. Accessed February 16, 2014.

13. Molassiotis A, Brearley S, Saunders M, et al. Effectiveness of a home care nursing program in the symptom management of patients with colorectal and breast cancer receiving oral chemotherapy: a randomized, controlled trial. J Clin Oncol. 2009;27:6191-6198.

14. Ream E. I'm just in the shadow to keep an eye: an investigation to understand the need for support in family members of people having chemotherapy. Macmillan Cancer Care; 2013. Available from: http:// public.ukcrn.org.uk/search/StudyDetail.aspx?StudyID=10054. Accessed February 16, 2014

15. Ream E, Pedersen V, Oakley C, Richardson A, Taylor C, Verity R. Informal carers' experiences and needs when supporting patients through chemotherapy: a mixed method study. Eur J Cancer Care (Engl). 2013;22:797-806.

16. Hewitt M, Greenfield S, Stovall E. From cancer patient to cancer survivor. Lost in transition. Committee on Cancer Survivorship: Improving Care and Quality of Life National Cancer Policy Board; 2005. Available from: http://www.nap.edu/openbook.php?isbn=0309095956. Accessed February 15, 2014.
17. National Cancer Survivorship Initiative. Concerns checklist. 2012. Available from: http://www.ncsi.org.uk/wp-content/uploads/MAC13689_ Identifying-concerns_Pad_v3.pdf. Accessed February 16, 2014.

18. Kearney N, McCann L, Norrie J, et al. Evaluation of a mobile phonebased, advanced symptom management system $\left(\mathrm{ASyMS}^{\circ}\right)$ in the management of chemotherapy-related toxicity. Support Care Cancer. 2009; 17:437-444.

19. Department of Health. Manual of Cancer Services; Acute Oncology Services. London, UK: National Cancer Peer Review, National Cancer Action Team; 2012. Available from: http:/www.cquins.nhs.uk Accessed September 20, 2013.

20. MacMillan Cancer Support. Chemotherapy. 2001. Available from: http:// www.macmillan.org.uk/Cancerinformation/Cancertreatment/Treatmenttypes/Chemotherapy/Chemotherapy.aspx. Accessed September 19, 2013.

21. Cancer Research UK. How chemotherapy works. http://www. cancerresearchuk.org/cancer-help/about cancer/treatment/chemotherapy/ about/how-chemotherapy-works. Accessed September 19, 2013.

22. MacMillan Cancer Support. The hidden price of getting treatment. 2006. MacMillan Cancer Support. Available from: http://www.macmillan. org.uk/Documents/GetInvolved/Campaigns/Campaigns/Cancercosts. pdf. Accessed February 15, 2014.

23. Oakley C, Lennan E, Roe H, Craven O, Harrold K, Vidall C. Safe practice and nursing care of patients receiving oral anti-cancer medicines; a position statement from UKONS. Ecancermedicalscience. 2010;4:177.

24. Multinational Association of Supportive Care in Cancer. MASCC ${ }^{\text {тм }}$ teaching tool for patients receiving oral agents for cancer. Available from: http://www.mascc.org/assets/documents/MOATT_English_2010. pdf. Accessed September 18, 2013.

25. http://www.teachbacktraining.org/Institute. [homepage on the Internet] Accessed November 13, 2013.

26. Finnegan-John J, Foster R, Lennan E, et al. A longitudinal qualitative interview study to understand need for support in family members of people having chemotherapy. Psycho-Oncology. 2013;22 Suppl 1:1.

27. Quality health (2014) Chemotherapy patient experience survey 2013 National report, National Health Service, England. Available from http://www.quality-health.co.uk/resources/surveys/national-cancerexperience-survey/2013-national-cancer-patient-exerience-survey. Accessed June 20, 2014.

28. National Cancer Institute. Cancer Therapy Evaluation Program. Common Toxicity Criteria Manual. Version 2.0. 1999. Available from: http://ctep.cancer.gov/protocolDevelopment/electronic_applications/ docs/ctcmanual_v4_10-4-99.pdf. Accessed April 23, 2010.

29. Baker J, Ajani J, Scotté F, et al. Docetaxel-related side effects and their management. Eur J Oncol Nurs. 2008;12:253-268.

30. National Institute for Clinical Excellence. Neutropenic sepsis: prevention and management of neutropenic sepsis in cancer patients Clinical guidelines, CG151. London, UK: National Institute for Clinical Excellence; 2012. Available from: http://publications.nice.org.uk/ neutropenic-sepsis-prevention-and-management-of-neutropenic-sepsisin-cancer-patients-cg151. Accessed February 16, 2014.

31. Young A, Crowe M, Lennan E, et al. Delivery of chemotherapy at planned dose and on time. Cancer Nurs Pract. 2009;8:16-19.

32. Hesketh PJ. Chemotherapy-induced nausea and vomiting. $N$ Engl $J$ Med. 2008;358:2482-2494.

33. Miller M, Kearney N. Chemotherapy-related nausea and vomiting - past reflections, present practice and future management. Eur J Cancer Care (Engl). 2004;13:71-81.

34. Grunberg SM. Chemotherapy-induced nausea and vomiting: prevention, detection, and treatment - how are we doing? J Support Oncol. 2004;2(Suppl 1):S1-S10.

35. Hickok JT, Roscoe JA, Morrow GR, King DK, Atkins JN, Fitch TR. Nausea and emesis remain significant problems of chemotherapy despite prophylaxis with 5-hydroxytriptamine-3 antiemetics: a University of Rochester James P. Wilmot Cancer Center Community Clinical Oncology Program study of 360 cancer patients treated in the community. Cancer. 2003;97:2880-2886. 
36. Armes J, Wagland R, Finnegan-John J, Richardson A, Corner J, Griffiths P. Development and testing of the patient-reported chemotherapy indicators of symptoms and experience: patient-reported outcome and process indicators sensitive to the quality of nursing care in ambulatory chemotherapy settings. Cancer Nurs. October 17, 2013. [Epub ahead of print.]

37. Vidall C, Dielenseger P, Farrell C, et al. Evidence-based management of chemotherapy-induced nausea and vomiting: a position statement from a European cancer nursing forum. Ecancermedicalscience. 2011;5:211.

38. Middleton J, Lennan E. Effectively managing chemotherapyinduced nausea and vomiting. Br J Nurs. 2011;20:S7-S8, S10-S12, S14-S15.

39. American Society of Clinical Oncology. Available from: http:// www.asco.org/guidelines/chemotherapyinducednauseaandvomiting/. Accessed November 24, 2013.

40. Dibble SL, Luce J, Cooper BA, et al. Acupressure for chemotherapyinduced nausea and vomiting: a randomized clinical trial. Oncol Nurs Forum. 2007:34:813-820.

41. Ezzo JM, Richardson MA, Vickers A, et al. Acupuncture-point stimulation for chemotherapy-induced nausea or vomiting. Cochrane Database Syst Rev. 2006;2:CD002285.

42. Ernst E, Pittler MH. Efficacy of ginger for nausea and vomiting: a systematic review of the randomized clinical trials. $\mathrm{Br} J$ Anaesth. 2000;84:367-371.

43. Eckert RM. Understanding anticipatory nausea. Oncol Nurs Forum. 2001;28:1553-1558.

44. Shelke AR, Roscoe JA, Morrow GR, Colman LK, Banerjee TK, Kirshner JJ. Effect of a nausea expectancy manipulation on chemotherapyinduced nausea: a university of Rochester cancer center community clinical oncology program study. J Pain Symptom Manage. 2008;35:381-387.

45. Benson AB 3rd, Ajani JA, Catalano RB, et al. Recommended guidelines for the treatment of cancer treatment-induced diarrhea. J Clin Oncol. 2004;22:2918-2926.

46. Kornblau S, Benson AB, Catalano R, et al. Management of cancer treatment-related diarrhea. Issues and therapeutic strategies. $J$ Pain Symptom Manage. 2000;19:118-129.

47. Gebbia V, Carreca I, Testa A, et al. Subcutaneous octreotide versus oral loperamide in the treatment of diarrhea following chemotherapy. Anticancer Drugs. 1993;4:443-445.

48. Richardson G, Dobish R. Chemotherapy induced diarrhea. J Oncol Pharm Pract. 2007;13:181-198.

49. Gibson RJ, Keefe DM. Cancer chemotherapy-induced diarrhoea and constipation: mechanisms of damage and prevention strategies. Support Care Cancer. 2006;14:890-900.

50. Massey C. A multicenter study to determine the efficacy and patient acceptability of the Paxman scalp cooler to prevent hair loss in patients receiving chemotherapy. Eur J Oncol Nurs. 2004;8:121-130.

51. Roe H. Chemotherapy-induced alopecia: advice and support for hair loss. Br J Nurs. 2011a;20:S4-S11.

52. Hilton S, Hunt K, Emslie C, Salinas M, Ziebland S. Have men been overlooked? A comparison of young men and women's experiences of chemotherapy-induced alopecia. Psycho-Oncology. 2008;7:577-583.

53. Yeager CE, Olsen EA. Treatment of chemotherapy-induced alopecia. Dermatol Ther. 2011;24:432-442.

54. Hunt NC. The Viviscal Report; the hidden impact of hair loss. 2009. Available from: http://www.managinghairloss.com/_pdf/Hair-lossreport-summary.pdf. Accessed January 5, 2014.

55. Mynewhair. Advice and support if you lose your hair. 2011. Available from: http://www.mynewhair.org. Accessed September 15, 2013.

56. Treister N, Sook-Bin W. Chemotherapy-induced oral mucositis. 2008. Available from: http://emedicine.medscape.com/article/1079570overview. Accessed February 16, 2014.

57. Borbasi Cameron K, Quested B, Olver I, To B, Evans D. More than a sore mouth: patients' experience of oral mucositis. Oncol Nurs Forum. 2002;29:1051-1057.

58. Mais K. Mucositis from radiotherapy to the head and neck: an overview. Oncology News. 2006;1. Available from: http://www.oncologynews.biz/ pdf/jun_jul/ON_junjul06_18.pdf. Accessed February 16, 2014.
59. UK Oral Mucositis in Cancer Group. OM guidelines. Available from http://www.ukomic.co.uk/new-om-guidelines.html. Accessed Sep 2013.

60. Rehwaldt M, Wickham R. Purl S, et al. Self care strategies to cope with taste changes after chemotherapy. Oncology Nursing Forum. 2009;36(2):E47-E56.

61. Sánchez-Lara K, Sosa-Sánchez R, Green-Renner D, et al. Influence of taste disorders on dietary behaviors in cancer patients under chemotherapy. Nutr J. 2010;9:15.

62. Steinback S, Hummel T, Böhner C, et al. Qualitative and quantitative assessment of taste and smell changes in patients undergoing chemotherapy for breast and gynecologic malignancies. J Clin Oncol. 2009;27:1899-1905.

63. Bernhardson BM, Tishelman C, Rutqvist LE. Self-reported taste and smell changes during cancer chemotherapy. Support Care Cancer. 2008; 16:275-283.

64. Schlairet M, Heddon M, Griffis M. Piloting a needs assessment to guide development of a survivorship program for a community cancer center. Oncol Nurs Forum. 2010;37:501-508.

65. Bower JE, Ganz PA, Desmond KA, Rowland JH, Meyerowitz BE, Belin TR. Fatigue in breast cancer survivors: occurrence, correlates, and impact on quality of life. J Clin Oncol. 2000;18:743-753.

66. Broeckel JA, Jacobsen PB, Horton J, Balducci L, Lyman GH. Characteristics and correlates of fatigue after adjuvant chemotherapy for breast cancer. J Clin Oncol. 1998;16:1689-1696.

67. Nyholm CB. Side effects of cancer treatment: "chemo head" chemotherapy causes chemo brain. Available from: http://voices.yahoo. com/side-effects-cancer-treatment-chemo-head-389300.html?cat $=68$. Accessed February 16, 2014

68. British Pharmacological Society. 2013. Available from: http://www.bps. ac.uk/view/index.html. Accessed February 14, 2014.

69. Resuscitation Council. Emergency treatment of anaphylactic reactions. Guidelines for healthcare providers. Available from http://www. resus.org.uk/pages/reaction.pdf\#search="anaphylaxis2. Accessed September 16, 2013.

70. Lee C, Gianos M, Klaustermeyer W. Diagnosis and management of hypersensitivity reactions related to common chemotherapy agents. Ann Allergy Asthma Immunol. 2009;102:179-187.

71. http://www.neuropathy.org/site/PageServer. [webpage on the Internet]. Accessed December 30, 2013.

72. Pérez Fidalgo JA, García Fabregat L, Cervantes A, Margulies A, Vidall C, Roila F; ESMO Guidelines Working Group. Management of chemotherapy extravasation; ESMO-EONS clinical practice guidelines. Eur J Oncol Nurs. 2012;16:528-534.

73. Schulmeister L. Extravasation management; clinical update. Semin Oncol Nurs. 2011;27:82-90.

74. Roe H. Anthracycline extravasations; prevention and management. $\mathrm{Br}$ J Nurs. 2011b;20:S16-S22.

75. Vidall C, Roe H, Dougherty L, Harrold K. Dexrazonane: a management option for anthracycline extravasations. Br J Nurs. 2013;22: S6-S12.

76. United Kingdom Oncology Nursing Society. Anthracycline Extravasation Management Guidelines. London, UK: United Kingdom Oncology Nursing Society; 2008.

77. National Cancer Institute Common toxicity criteria http://ctep.cancer. gov/protocolDevelopment/electronic_applications/ctc.htm. [webpage on the Internet]. Accessed December 30, 2013.

78. DPfizer Oncology. Acute Oncology Service: implementation of a nurse-led, integrated acute oncology service - Pan Birmingham Cancer Network and Sandwell and West Birmingham Hospitals NHS Trust. Available from: http://connect.qualityincare.org/oncology/patient_safety/ case_studies/acute_oncology_service_implementation_of_a_nurse_ led,_integrated_acute_oncology_service_pan_birmingham_cancer_ network_and_sandwell_and_west_birmingham_hospitals_nhs_trust. [webpage on the Internet]. Accessed December 30, 2013.

79. National Cancer Institute. Common Terminology Criteria for Adverse Events (CTCAE) Version 4.0. Available from: http://evs.nci.nih.gov/ $\mathrm{ftp} 1 / \mathrm{CTCAE} / \mathrm{CTCAE}$ 4.03_2010-06-14_QuickReference_8.5x11.pdf. Accessed February 2012. 
Nursing: Research and Reviews

\section{Publish your work in this journal}

Nursing: Research and Reviews is an international, peer-reviewed, open access journal publishing original research, reports, reviews and commentaries on all aspects of nursing and patient care. These include patient education and counselling, ethics, management and organizational issues, diagnostics and prescribing, economics and

resource management, health outcomes, and improving patient safety in all settings. The manuscript management system is completely online and includes a very quick and fair peer-review system. Visit http://www.dovepress.com/testimonials.php to read real quotes from published authors.

Submit your manuscript here: http://www.dovepress.com/nursing-research-and-reviews-journal 